\title{
TEMPORAL RESPONSE OF CALIFORNIA BLACK RAILS TO TIDAL WETLAND RESTORATION
}

\author{
JULES EVENS, P.O. Box 839, Point Reyes Station, California 94956; \\ avocetra@gmail.com
}

\begin{abstract}
From the mid-1800s into the 1960s, many tidal wetlands along the coast of California were isolated from tidal influence and converted to farmland. Since 1976, to restore ecological function and hydrological integrity, tidal influence has been restored to some of these wetlands. My collaborators and I monitored three sites-one on the north edge of San Pablo Bay, one on the west side of San Francisco Bay, and one at the south end of Tomales Bay-to document occupancy by the California Black Rail (Laterallus jamaicensis coturniculus), a cryptic marsh bird with an extremely narrow habitat niche in emergent tidal wetlands and considered an indicator of tidal-marsh health and restoration success. A source of prospective colonists had persisted adjacent to all three sites. Black Rails occupied each site within three to ten years, demonstrating the value of these restorations.
\end{abstract}

In 1971, the California Black Rail (Laterallus jamaicensis coturniculus) was designated as threatened under the California Endangered Species Act because of its limited distribution and historic loss of habitat (Evens et al. 1991, Goals Project 1999). The taxon is extirpated as a nesting species in coastal southern California south of Morro Bay (Garrett and Dunn 1981, Unitt 1984). The absence of confirmed detections since 2005, despite intensive surveys in 2010 and 2011, indicate that it is probably extirpated from Morro Bay also (T. Edell pers. comm., Rosen 2011). Small populations occur in freshwater swales of the foothills of the Sierra Nevada (Aigner et al. 1995, Richmond et al. 2008) and in wetland seeps along the lower Colorado River and in the Salton Basin (Evens et al. 1991, Patten et al. 2003, Conway and Sulzman 2007). But population estimates and the extent of available habitat imply that well over $90 \%$ of the California Black Rail's population is associated with the tidal marshes of San Francisco Bay and wetlands along the nearby outer coast (Evens and Nur 2002). Around San Francisco Bay the Black Rail typically occupies tidal marshes at elevations ranging from 1.5 to $2.0 \mathrm{~m}$ above sea level (with respect to the North American Vertical Datum of 1988). Since the mid-1800s, agriculture, salt production, and urbanization have reduced the historic tidal marshlands of the San Francisco Bay estuary by an estimated $78-85 \%$, and species dependent on tidal marshes have been reduced concomitantly (Nichols et al. 1986, Goals Project 1999).

Habitat critical to the Black Rail is at imminent risk due to increases in frequencies of extreme weather and sea-level rise associated with climate change. These factors are expected to result in increased flooding of marshes' main surface (the "high marsh plain") and loss of intertidal wetlands (Evens and Thorne 2015, Stralberg et al. 2011, Thorne et al. 2012). During periods of inundation, species dependent on tidal marshes, such as the Black Rail, typically take temporary refuge in adjacent vegetated uplands to avoid drowning and predation (Evens and Page 1986, Thorne et al. 2012). The extent of adjacent upland habitat has decreased with the urbanization of the estuary and the hardening of its edges with infrastructure such as roads, levees, breakwaters, and rip-rap (Nichols et al. 1986), further reducing habitat quality 


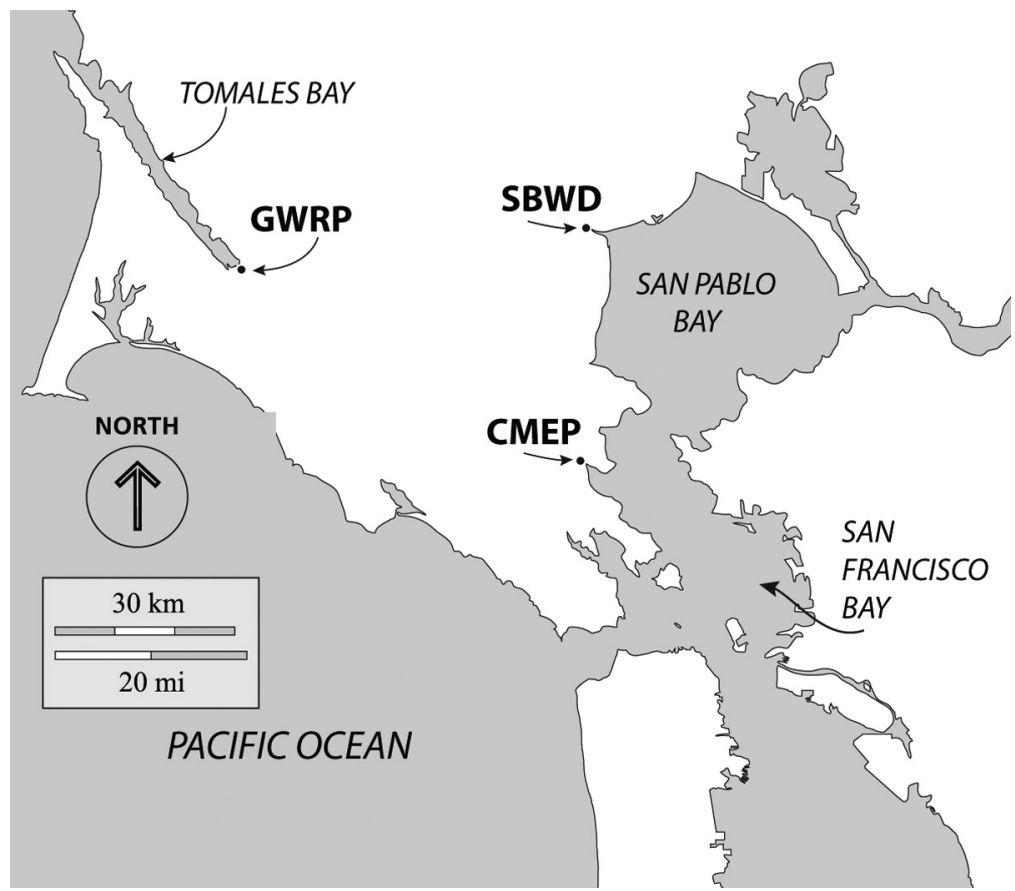

FiguRE 1. Locations of the three restored wetlands in the San Francisco Bay area. SBWD, Sonoma Baylands Wetland Demonstration; CMEP, Corte Madera Ecological Preserve; GWRP, Giacomini Wetland Restoration Project.

for species dependent on tidal marshes. To address this loss and to improve habitat quality, in recent years refugial habitat from high tides and flooding has been incorporated into the design of restorations (e.g., NPS 2012).

Here I summarize the results of intermittent and continuing surveys for the Black Rail at three sites of tidal-marsh restoration in Marin and Sonoma counties, California: the Giacomini Wetland Restoration Project, Tomales Bay, Point Reyes National Seashore; the Corte Madera Ecological Reserve and Muzzi Marsh, along the west shore of San Francisco Bay; and the Sonoma Baylands Wetland Demonstration, along the north shore of San Pablo Bay.

\section{STUDY AREA}

Following the restoration of tidal influence, at each site the marsh plain regenerated vegetation characteristic of central California's tidal marshes. Typically, the lower elevations of sloughs and bayshore are colonized by cordgrass (Spartina foliosa). In the middle elevation zone, at about mean high water, pickleweed (Sarcocornia pacifica) tends to dominate but often in association with salt grass (Distichlis spicata), alkali heath (Frankenia salina), gumplant (Grindelia stricta), and marsh jaumea (Jaumea carnosa). On the outer coast, 


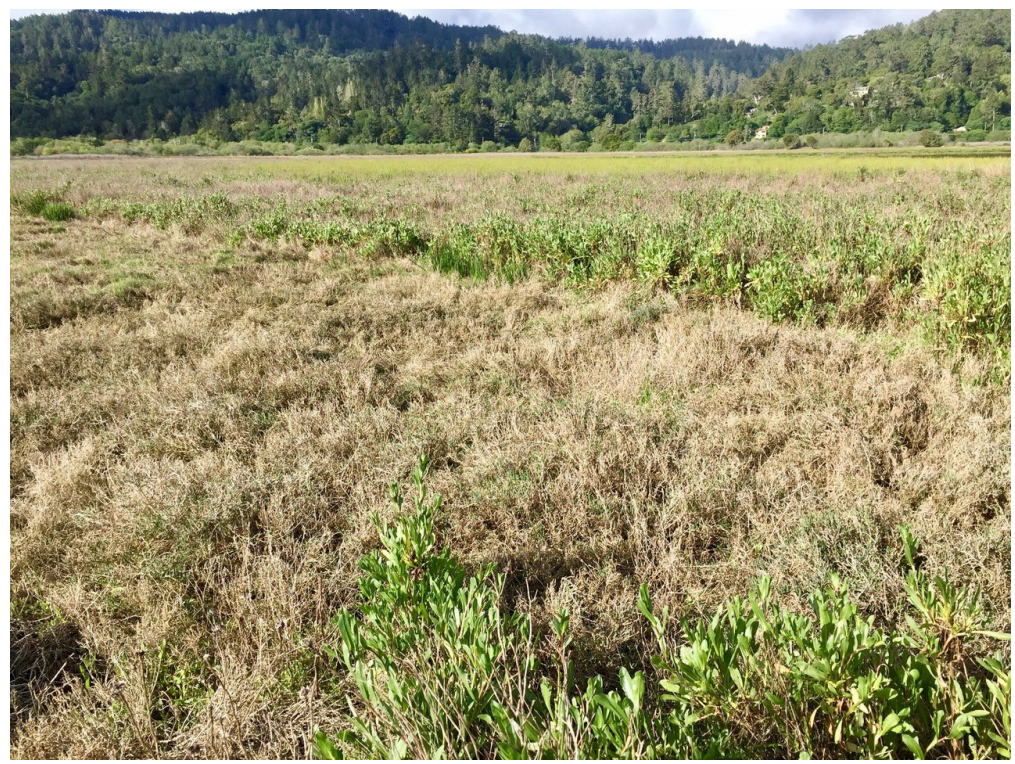

Figure 2. Occupied California Black Rail habitat, Giacomini Wetlands, Tomales Bay, 29 April 2018. The vegetative community is typical of tidal salt marshes between mean high water and mean higher high water on the central California coast. Pickleweed is dominant on the marsh plain with bushy gumplant at slightly higher microelevations. The understory may be an admixture of marsh jaumea, saltgrass, and at slightly higher elevations alkali heath.

at Tomales Bay, or where the water is brackish, sea arrowgrass (Triglochin) joins the community of halophytes. Where freshwater enters the upper marsh, sedges (e.g., Schoenoplectus), rushes (Juncus), and cattails (Typha) may form discrete patches. The ecotones between these patches and the more saline marsh community are often "hotspots" for the Black Rail. Once established, these mosaics of marsh-plant communities typically provide nearly complete vegetative cover (90 to 100\%), a critical component of Black Rail habitat.

Giacomini Wetland Restoration Project, Tomales Bay, Point Reyes National Seashore

In the late $19^{\text {th }}$ and early $20^{\text {th }}$ centuries, Black Rails occurred in tidal marshlands in the southern reach of Tomales Bay, which Grinnell and Miller (1944:130) mentioned as the location in California where the species was "noted most frequently." In 1946, 222.6 ha of the marshland of southern Tomales Bay was isolated from tidal influence by a system of levees, tide gates, and culverts, effectively converting tidal marsh to pastureland for a dairy ranch, which operated until the land was purchased by the National Park Service in 2001 (NPS 2012). This conversion eliminated approximately $50 \%$ of the emergent marshland in the bay and the preponderance of Black 
Rail habitat. In 2008, with the Giacomini Wetland Restoration Project under the auspices of the National Park Service, tidal influence was restored (NPS 2012). Salt-marsh plants colonized the restored wetlands on their own. Land managers planted the high marsh-upland ecotone with species such as coyote bush (Baccharis pilularis) and wild rye (Elymus triticoides) to provide refugial habitat at high tide (L. Parsons pers. comm.).

In the decades preceding the restoration there still existed, adjacent to and just north of the restoration site, some mature marsh, the Tomales Bay Ecological Preserve, in which the tides were unrestricted and human intrusion was minimal. When surveyed in 1986 and 1987, before the restoration, this mature marsh supported a Black Rail population of moderate density (0.6-2.1 rails per hectare) (Evens et al. 1991). During winter flood tides, birders stood on the northernmost levee to observe rails as they left the marsh vegetation to take refuge in adjacent upland or emergent vegetation until the waters subsided (Evens and Page 1986).

After the National Park Service purchased the area that had been diked, the annual harvest of hay was discontinued. Cattle grazing was reduced, then discontinued completely in 2007. In October 2008, the levees were razed and tidal influence was restored.

\section{Corte Madera Ecological Reserve and Muzzi Marsh}

This complex of tidal wetlands is located along the western shore of San Francisco Bay, Marin County. It contains 59 ha of emergent marshlands of which 38 ha are in the Corte Madera Ecological Reserve and 21 ha are in the adjacent Muzzi Marsh, remnants of formerly more extensive marshes. Beginning in 1853, existing marshes expanded into the bay, onto sediment deposited from hydraulic gold mining in the Sierra Nevada. After hydraulic mining ceased in 1884, the site was diked off from tidal action. In the 1920 s portions of the Corte Madera marshes were drained for hayfields and cattle grazing (Haehl 2002). In the early 1950s portions were used for dredge-spoil disposal. In the 1960s, levees were built along the bayshore, and the enclosed area was used as pastureland. Under a restoration begun in 1976, cattle grazing was eliminated, the outer levees were breached in 1977, and tidal flow to the sites was restored (Williams and Faber 2001, Harris 2008, CDFW 2018). Sedimentation raised the marsh plain by about $2.5 \mathrm{~cm}$ per year and allowed cordgrass to become established. All the revegetation of the site was natural; no planting was done (J. Haltiner pers. comm.).

\section{Sonoma Baylands Wetland Demonstration}

This site covers 130 ha of formerly diked farmland in southwestern Sonoma County on the northern shoreline of San Pablo Bay. The 117-ha interior of the restoration site was designed to restore the ecological function of a tidal marsh. The site was once part of an extensive system of tidal wetlands along the north margin of San Pablo Bay with an original elevation approximately equal to mean higher high water (1.05 m; National Geodetic Vertical Datum of 1929) (Williams and Florsheim 1994, SER 2019). After its conversion from tidal marsh to farmland in the mid-1800s, the land subsided up to nearly 2 m below mean tide level. From 1993 to 1996 more than 2.0 million cubic meters of dredge spoils from the Petaluma River and the port of Oakland 
were deposited behind the levees to bring the surface of the marsh plain up to the level of mean higher high water (Marcus 2000). The substrate was graded to approximate original elevations, channels were carved to mimic natural marsh drainages, and the site was opened to tidal action on 25 October 1996.

The Sonoma Baylands were designed for natural revegetation. Annual pickleweed and gumplant colonized the site the first year after restoration (Phil Williams pers. comm.).

\section{METHODS}

My collaborators and I surveyed for the Black Rail by point counts, broadcasting taped or digital recordings of the species' vocalizations at each point in an attempt to elicit vocal responses, the primary means of detection (Evens et al. 1991, Spear et al. 1999, Evens and Nur 2002, Conway and Seamans 2016). All censuses took place between dawn and 09:30 Pacific Standard Time from mid-March through mid-May and were repeated up to three times per year. Coverage of the sites spanned four decades within 3 to 8 years following the restoration of tidal influence. Years of coverage were as follows: Corte Madera Marsh complex, 1981-1987; Sonoma Baylands, 2004 and 2015; Giacomini Wetlands, 2011-2019.

After arriving at a count point, the observer stood silently for 1.0 minute before broadcasting 1.0 minute of vocalizations. The call sequence consisted of 0.5 minute of repetitive "grr-grr-grr" calls followed by 0.5 minute of "kikkik-kerr" calls (Eddleman et al. 1994). Following the broadcast, the observer waited silently for 4.0 minutes before moving on the next point. Points were spaced at intervals of 50-200 m (depending on local topography) to avoid duplicative detections. The number of rails at each station was determined by the sum of the responses detected from a different compass direction $\left(>30^{\circ}\right)$ within $30 \mathrm{~m}$ of the observer during the 5 -min census period. The observer considered all calls coming from one direction to represent a single rail unless two or more calls were heard simultaneously; calls from different directions $\left(>30^{\circ}\right.$ apart) were considered different individuals. In earlier field testing, Gary Page, Lynne Stenzel, and I determined that observers were able to estimate the distance of vocalizations accurately up to approximately 30 $\mathrm{m}$ and that the observer's ability to estimate distance accurately, or to hear soft vocalizations consistently, declined beyond that distance (unpubl. data). Also, Evens and Nur (2002) estimated that during a 5-minute survey Black Rails move toward the source of a broadcast by an average of $6.2 \mathrm{~m}$. Therefore, my collaborators and I counted only detections within $30 \mathrm{~m}$ of the observer, but calculated abundance indices under the assumption that the effective radius of each sampling station was $36.2 \mathrm{~m}$, thus covering an area of 0.412 ha. Spear et al. (1999) also added this 6.2-m correction factor and found a high degree of conformance with expected detection values. My collaborators and I ranked the Black Rail's abundance around each point from the density index calculated for the plot within a radius of $36.2 \mathrm{~m}$ of each point as follows: low, $<0.6$ rails per hectare; moderate, $0.6-2.1$ rails per hectare; high, $2.1-3.8$ rails per hectare (Evens and Nur 2002). 


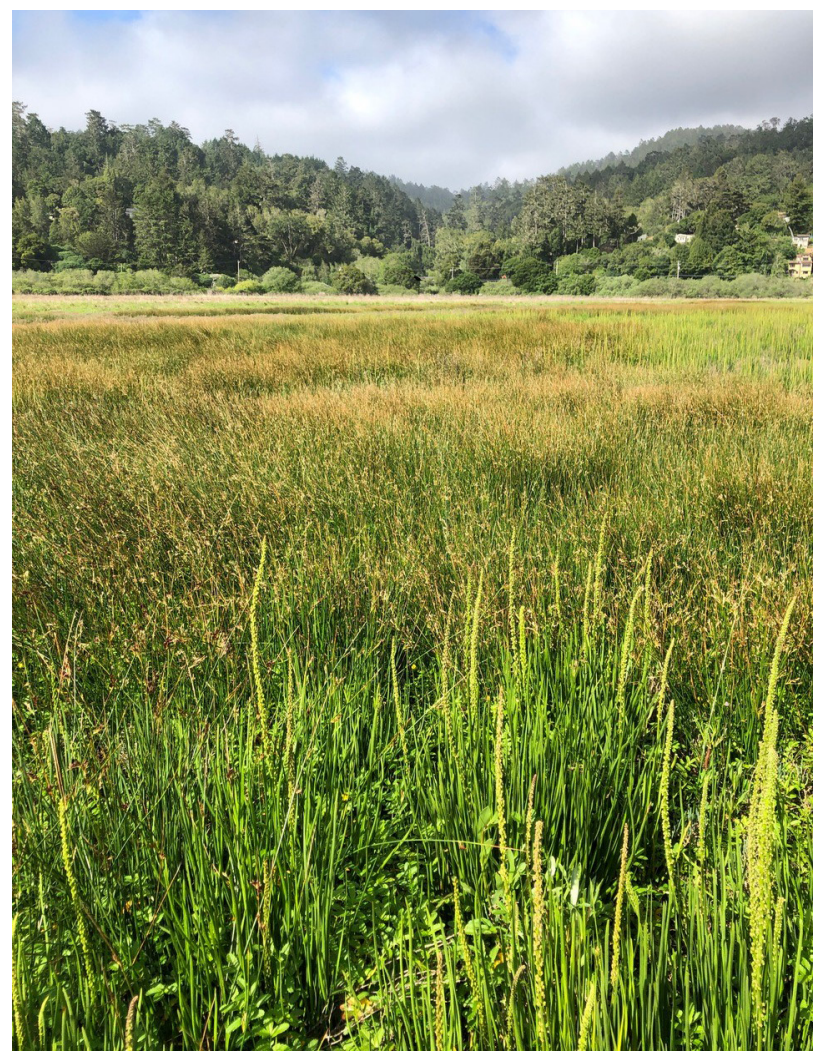

FIgURE 3. Brackish marsh at Giacomini Wetlands, Tomales Bay, 27 April 2019. Black Rails also occupy more brackish portions of the marsh bordering the salt marsh. Dense stands of sea arrowgrass in the foreground adjoining rushes. Cattails also occur, often in discrete stands, in these brackish situations.

\section{RESULTS}

\section{Giacomini Wetland Restoration Project}

Prior to restoration Black Rails were absent from this site, except as temporary refugees during extreme flooding (Evens and Page 1986, unpubl. data). Following restoration, the staff of Point Reyes National Seashore initiated a program to monitor changes in waterbirds' use of the site. As part of this effort, we selectively surveyed for the Black Rail in patches of likely habitat within the site. Black Rails were first detected within the site in 2011, three years after restoration (ARA 2019). The source of these initial colonizers was most likely the mature, fully tidal marsh adjacent to the northernmost levee where we had detected low to moderate densities during surveys in 1988 and 1996 (Evens and Nur 2002). Post-restoration surveys revealed that between 2012 
TABLE 1 Results of Surveys for the Black Rail in the Restored Giacomini Wetlands, Tomales Bay, California

\begin{tabular}{ccccccc}
\hline & $\begin{array}{c}\text { Survey } \\
\text { points }(n)\end{array}$ & $\begin{array}{c}\text { Detections } \\
(n)\end{array}$ & $\begin{array}{c}\text { Percentage of } \\
\text { points with } \\
\text { detections }\end{array}$ & $\begin{array}{c}\text { Mean number } \\
\text { of detections per } \\
\text { point surveyed }\end{array}$ & $\begin{array}{c}\text { Estimated } \\
\text { deviation }\end{array}$ & $\begin{array}{c}\text { density (per } \\
\text { hectare) })^{a}\end{array}$ \\
\hline 2011 & 17 & 2 & 12 & 0.12 & 0.32 & 0.3 \\
2012 & 20 & 6 & 10 & 0.25 & 0.62 & 0.7 \\
2016 & 9 & 9 & 44 & 0.67 & 0.94 & 1.0 \\
2018 & 19 & 15 & 53 & 0.79 & 1.32 & 1.9 \\
2019 & 48 & 57 & 69 & 1.24 & 1.32 & 2.9 \\
\hline
\end{tabular}

${ }^{a}$ Based on highest rate of detection that year at each point surveyed.

and 2019 the Black Rail's numbers increased and its distribution expanded as the marsh within the restoration site developed and matured. The population increased most sharply from 2016 to 2019 (Table 1). As of 2019, Black Rails occupied the entire site at moderate to high densities (ARA 2019). Eleven years after restoration, the birds had colonized newly established high-marsh habitat extensively (ARA 2019).

\section{Corte Madera Ecological Reserve and Muzzi Marsh}

Black Rails were first detected, fortuitously, at Corte Madera Ecological Reserve on 10 December 1981, with four heard during systematic surveys for California Ridgway's Rail (Rallus obsoletus obsoletus). Northern Harrier (Circus hudsonius) predation on single Black Rails was observed three times in 1982: 22 August, 29 November, and 30 December (unpubl. data). The August date implies that the species was resident and likely nesting. Therefore, Black Rails colonized the site five to six years after the restoration of tidal influence.

Between 23 February and 26 March 1987, Page and Evens (1987) detected Black Rails vocalizing ("kik-kik-kerr") spontaneously in Muzzi Marsh. Although this marsh was not surveyed for Black Rails systematically, the species was both heard and seen subsequently in areas elevated at and above the level of mean high water. Thus, within a decade following restoration, Black Rails had effectively occupied Muzzi Marsh, where they still persist (pers. obs.).

\section{Sonoma Baylands Wetland Demonstration}

Before restoration, moderate to high densities of Black Rails occurred in the adjacent fully tidal marsh on the bayshore side of the diked area (Evens and Nur 2002). The species was first detected inside the restoration site by Rich Stallcup, who heard a single bird calling in a marsh of emergent pickleweed on 23 March 2004, eight years after restoration. During the winter of 2014-2015 S. Bunnell and I surveyed the emergent Sarcocornia-dominated marsh in the southwest corner of the restoration area. We detected Black Rails in moderate density at three of the five stations. The Black Rail's colonization of the Sonoma Baylands further supports the observations at the other sites that the species will spread into tidal marshes regenerating in restoration sites that are adjacent to occupied habitat in fewer than ten years. 


\section{DISCUSSION}

The Black Rail's occurrence along irrigation ditches in the Sierra Nevada foothills and in the Salton Basin attests to its ability to colonize patchy habitats at some distance from source populations. The site in the Sierra foothills site of Yuba County is $>100 \mathrm{~km}$ from the next nearest known populations in the Sacramento-San Joaquin River delta (Manolis 1978, Evens et al. 1991, Aigner et al. 1995, Tsao et al. 2015), yet in a genetic and isotopic study Hall and Beissinger (2017) inferred a modest degree of movement between these two populations. This foothill habitat became established "sometime between 1977 and 1986" but did not exist earlier; Black Rails were first detected in these newly created wetlands in June 1994 (Aigner et al. 1995:157). The species' occupancy of these foothill sites has declined since 2007 because of West Nile virus and drought (Van Schmidt et al. 2019). In the Salton Basin, the Black Rail was first reported in February 1947 (Patten et al. 2003) and small numbers continue into the present (G. McCaskie pers. comm.). The Salton Basin sites are at least $\sim 135 \mathrm{~km}$ from previously occupied habitats around San Diego Bay. About $80 \mathrm{~km}$ from the Salton Basin, at the Ciénega de Santa Clara, Sonora, the Black Rail was first detected in 1998, 21 years after the creation of this 18,000-hectare wetland (Hinojosa-Huerta et al. 2001).

Van Schmidt et al. (2019) described the Black Rail's dispersal ability as limited. But the observations I report suggest that under favorable conditions effective short-distance dispersal can be expected and that Black Rails readily occupy newly created habitats.

Sea-level rise, the increased frequency and intensity of storms associated with climate change, and land subsidence are predicted to put the California coast and San Francisco Bay at risk through the remainder of the $21^{\text {st }}$ century (Cayan et al. 2008, Shirzaei and Bürgmann 2018). Low-lying tidal wetlands will be the first emergent habitats to experience this increased inundation (Doehring et al. 2016), so a reduction in habitat for the Black Rail and other species associated with tidal marshes is expected (Thorne et al. 2012, Tsao et al. 2015). Restoration of tidal wetlands, especially along the upper edge of current high tides, may ameliorate the effects of increased inundation on the marshes' biota. The Black Rail's fairly rapid response at all three restoration sites that my colleagues and I surveyed demonstrates that the species should benefit from other such restorations.

The three case studies I describe, along with the colonization of other more isolated habitat patches, suggest that, like many rails, the Black Rail is more vagile than commonly assumed. This effective dispersal ability is supported by evidence of juveniles dispersing widely from breeding areas and appearing in atypical habitats (Eddleman et al. 1994). Indeed, extralimital records, including three from the Southeast Farallon Island off San Francisco (Grinnell and Miller 1944, DeSante and Ainley 1980), $30 \mathrm{~km}$ from available habitat, illustrate this concept. Effective dispersal ability offers some hope that the species can persist into the next century, given the availability of habitats provided by well-informed efforts at restoration.

Additionally, the Black Rail is one of a suite of vertebrate species dependent on the tidal marshes of the San Francisco Bay area-the Salt-marsh Harvest Mouse (Reithrodontomys raviventris), California Ridgway's Rail 
(Rallus obsoletus obsoletus), San Pablo California Vole (Microtus californicus sanpabloensis), Suisun Shrew (Sorex ornatus sinuosus), and three endemic races of the Song Sparrow (Melospiza melodia maxillaris, M. m. samuelis, $M$. $m$. pusillula). Restoration efforts designed to increase high tidal marshes and adjacent refugial habitat promise to serve this suite of species at risk as well.

\section{SUMMARY}

In the San Francisco Bay area, the Black Rail has a very narrow habitat niche within high-tidal marshes, at elevations approximating mean highest high water (Manolis 1978, Evens et al. 1991). The results I have reported illustrate the species' ability to colonize newly restored tidal marshes within 3 to 10 years after the restoration of tidal influence to historic tidal wetlands, but this ability will be challenged by increasing sea-level rise. Restoration efforts at the upland edges of existing emergent tidal marshes, as exemplified by the three projects I have discussed, and the Black Rail's ability to exploit regenerating tidal marshes, provide some hope for the species' persistence into the future.

\section{ACKNOWLEDGMENTS}

Max Brier, Seth Bunnell, Mary Anne Flett, R. Phillip Henderson, Stephen Laymon, Terry Nordbye, Gary Page, Rich Stallcup, Lynne Stenzel, Emilie Strauss, Nils Warnock, and David Wimpfheimer contributed to the field work on which this study is based. I thank Nadav Nur, Gary Page, and Lynn Stenzel for data analysis for the earlier studies referenced. Jeff Haltiner, Lorraine Parsons, Amelia Ryan, and Phil Williams provided information on the vegetative history of the restoration sites. Portions of this research were funded by the Bureau of Land Management, California Coastal Conservancy, California Department of Fish and Wildlife, Point Reyes National Seashore Association, the Hood Harris Fund for Conservation of Marin Audubon Society, and the U.S. Army Corps of Engineers, San Francisco District. Additional personal comments were generously provided by Guy McCaskie, Sean Peterson, and Jerry Tecklin. Earlier versions of this paper were improved by the editorial comments of Kenneth P. Able, Scott Terrill, and Philip Unitt.

\section{LITERATURE CITED}

Aigner, P. A., Tecklin, J., and Koehler, C. E. 1995. Probable breeding population of the Black Rail in Yuba County, California. W. Birds 26:157-160.

Avocet Research Associates. 2019. Status of the California Black Rail (Laterallus jamaicensis coturniculus), Giacomini Marsh Wetland Restoration, Point Reyes National Seashore: 2019. Final report to Point Reyes National Seashore, 1 Bear Valley Road, Point Reyes Station, CA 94956.

California Department of Fish and Wildlife. 2018. Corte Madera Ecological Reserve; www.wildlife.ca.gov/Lands/Places-to-Visit/Corte-Madera-MarshER\#10532119-history (accessed 1 September 2019).

Cayan, D. R., Bromirski, P. D., Hayhoe, K., Tyree, M., Dettinger, M. D., and Flick, R. E. 2008. Climate change projections of sea level extremes along the California coast. Climatic Change 87:57-73; doi.org/10.1007/s10584-007-9376-7.

Conway, C. J., and Seamans, M. E. 2015. National Wildlife Refuge system protocol framework for the inventory and monitoring of secretive marsh birds. Inven- 
tory and Monitoring, National Wildlife Refuge System, U.S. Fish and Wildlife Service, Fort Collins, CO; www.ecos.fws.gov/ServCat/Reference/Profile/52385.

Conway, C. J., and Sulzman, C. 2007. Status and habitat use of the California Black Rail in the southwestern USA. Wetlands 27:987-998; doi.org/10.1672/02775212(2007)27[987:SAHUOT]2.0.CO;2.

DeSante, D. F., and Ainley, D. G. 1980. The avifauna of the South Farallon Islands, California. Studies Avian Biol. 4.

Doehring, C., Beagle, J., Lowe, J., Grossinger, R. M., Salomon, M., Kauhanen, P., Nakata, S., Askevoid, R. A., and Bezalel, S. N. 2016. San Francisco Bay shore inventory: Mapping for sea level rise planning. SFEI Contr. 779. San Francisco Estuary Inst., Richmond, CA; www.sfei.org/documents/san-francisco-bayshore-inventory-mapping-sea-level-rise-planning.

Eddleman, W. R., Flores, R. E., and Legare, M. 1994. Black Rail (Laterallus jamaicensis), in Birds of North America (A. F. Poole and F. B. Gill, eds.), no. 123. Acad. Nat. Sci., Philadelphia; doi.org/10.2173/bna.123.

Evens, J., and Nur, N. 2002. California Black Rails in the San Francisco Bay region: Spatial and temporal variation in distribution and abundance. Bird Populations 6:1-12.

Evens, J. G., and Page, G. W. 1986. Predation of Black Rails during high tides in salt marshes. Condor 88:107; doi.org/10.2307/1367769.

Evens, J., and Thorne, K. 2015. California Black Rail (Laterallus jamaicensis coturniculus), in Baylands Ecosystem Habitat Goals Science Update (Science Foundation Chapter 5; Appendix 5.1-Case Study); www.baylandsgoals.org/ wp-content/uploads/2015/10/BEHGU_5.1_CaseStudy_BlackRail.pdf.

Evens, J., Page, G. W., Stenzel, L. E., Laymon, S. A., and Stallcup, R. W. 1991. Distribution, relative abundance, and status of the California Black Rail in western North America. Condor 93:952-966; doi.org/10.2307/3247730.

Garrett, K. L. and Dunn, J. L. 1981. Birds of Southern California: Status and Distribution. Los Angeles Audubon Soc., Los Angeles.

Goals Project. 1999. Baylands ecosystem habitat goals. A report of habitat recommendations prepared by the San Francisco Bay Area Wetlands Ecosystem Goals Project. U.S. Environmental Protection Agency, San Francisco/San Francisco Bay Regional Water Quality Control Board, Oakland.

Grinnell, J., and Miller, A. H. 1944. The distribution of the birds of California. Pac. Coast Avifauna 27.

Haehl, J. (ed.). 2002. A History of Corte Madera. Corte Madera Community Foundation, P.O. Box 7109, Corte Madera, CA 94976; www.cortemaderamemories.org/ uploads/6/3/5/4/63546529/a_history_of_corte_madera_1.pdf.

Hall, L., and Beissinger, S. R. 2017. Inferring the timing of long-distance dispersal between rail metapopulations using genetic and isotopic assignments. Ecol. Appl. 27:208-218; doi.org/10.1002/eap.1432.

Harris, R. 2008. The Corte Madera marshes. Friends of Corte Madera Creek Watershed, P.O. Box 415, Larkspur, CA 94977; www.friendsofcortemaderacreek.org/ $\mathrm{cn} /$ thecortemaderamarshes.pdf.

Hinojosa-Huerta, O., Shaw, W. M., and DeStefano, S. 2001. Detections of California Black Rails in the Colorado River delta, Mexico. W. Birds 32:228-232.

Manolis, T. 1978. Status of the Black Rail in central California. W. Birds 9:151-158.

Marcus, L. 2000. Restoring tidal wetlands at Sonoma Baylands, San Francisco Bay, California. Ecol. Engineering 15:373-383; doi.org/10.1016/S09258574(00)00087-2.

National Park Service (NPS) 2012. Giacomini Wetlands restoration: A legacy for Tomales Bay; www.nps.gov/pore/learn/management/upload/planning_giacomini_wrp_legacyfortomalesbay_081026.pdf. 
Nichols F. H., Cloern, J. E., Luoma, S. N., and Peterson D.H. 1986. The modification of an estuary. Science 231:567-573; doi.org/10.1126/science.231.4738.567.

Page, G. W., and Evens, J. G. 1987. The sizes of Clapper Rail populations at Corte Madera Ecological Reserve, Muzzi Marsh, San Clemente Creek, and Triangle Marsh. Report to Marin Audubon Society from Point Reyes Bird Observatory (contribution 367) (order from Avocet Research, P.O. Box 839, Point Reyes Station, CA 94956).

Patten, M. A., McCaskie, G., and Unitt, P. 2003. Birds of the Salton Sea: Status, Biogeography, and Ecology. Univ. of Calif. Press, Berkeley; doi.org/10.1525/ california/9780520235939.001.0001.

Richmond, O. M., Tecklin, J., and Beissinger, S. R. 2008. Distribution of California Black Rails in the Sierra Nevada foothills. J. Field Ornithol. 79:381-390; doi. org/10.1111/j.1557-9263.2008.00195.x.

Rosen, J. 2011. An assessment of the current (2009-2010) and historic status of the California Black Rail at Morro Bay, California. Report to the Morro Bay Audubon Society and Morro Bay National Estuary Program, 601 Embarcadero, Suite 11, Morro Bay, CA 93442.

Shirzaei, M., and Bürgmann, R. 2018. Global climate change and local land subsidence exacerbate inundation risk to the San Francisco Bay area. Sci. Adv. 4(3):eaap9234; doi.org/10.1126/sciadv.aap9234.

Society for Ecological Restoration (SER). 2019. USA: California: Restoring tidal wetlands at Sonoma Baylands, San Francisco Bay; www.ser-rrc.org/project/usacalifornia-restoring-tidal-wetlands-at-sonoma-baylands-san-francisco-bay/.

Spear, L.B., Terrill, S. B., Lenihan, C., and Delevoryas, P. 1999. Effects of temporal and environmental factors on the probability of detecting California Black Rails. J. Field Ornithol. 70:465-480.

Stralberg, D. M., Brennan, M., Callaway, J. C., Wood, J. K., Schile, L. M., Jongsomjit, D., Kelly, M., Parker, V. T, and Crooks, S. 2011. Evaluating tidal marsh sustainability in the face of sea-level rise: A hybrid modeling approach applied to San Francisco Bay. PLoS One 6(11): e27388; doi:10.1371/journal.pone.0027388.

Thorne, K. M., Takekawa, J. Y., and Elliott-Fisk, D. L. 2012. Ecological effects of climate change on salt marsh wildlife: A case study from a highly urbanized estuary. J. Coastal Res. 28:1477-1487; doi.org/10.2112/JCOASTRES-D-11-00136.1.

Tsao, D. C., Melcer, R. E., and Bradbury, M. 2015. Distribution and habitat associations of California Black Rail (Laterallus jamaicensis coturniculus) in the Sacramento-San Joaquin delta. San Francisco Estuary Watershed Sci. 13(4); doi.org/10.15447/sfews.2015v13iss4art4.

Unitt, P. 1984. The birds of San Diego County. San Diego Soc. Nat. Hist. Memoir 13.

Van Schmidt, N. D., Kovach, T., Kilpatrick, A. M., Oviedo, J. L., Huntsinger, L., Hruska, T., Miller. N. L., and Beissinger, S. R. 2019. Integrating social and ecological data to model metapopulation dynamics in coupled human and natural systems. Ecology 100(6):e02711; doi.org/10.1002/ecy.2711.

Williams, P. B., and Faber, P. B. 2001. Salt marsh restoration experience in San Francisco Bay. J. Coastal Res. Special Issue 27:203-311.

Williams, P. B., and Florsheim, J. 1994. Designing the Sonoma Baylands Project. Coast \& Ocean 10(2):19-27. 